\title{
EFFECTS OF FORMULATION AND PROCESSING METHODS ON THE QUALITY AND ACCEPTABILITY OF CUTLETS MADE FROM MINCED MEAT OF PANGAS (Pangasius pangasius)
}

\author{
Vijay Kumar Reddy. S* \\ Department of Harvest and Post-harvest Technology, College of Fisheries \\ GADVASU, Ludhiana, Punjab, India - 141004
}

\begin{abstract}
The cutlets prepared in eight different combinations from minced meat of pangas (Pangasius pangasius) were studied for their nutritional composition, texture profile and acceptability. The effects of processing methods on quality of cutlets were also evaluated. Protein, fat and ash contents of the cutlets prepared in different combinations ranged between $13.37 \pm 0.38$ to $19.73 \pm 0.01 \% ; 11.05 \pm 0.14$ to $13.98 \pm 0.07 \%$ and $1.81 \pm 0.03$ to $5.59 \pm 0.22 \%$ respectively. More protein and fat contents, less hardness and cutting strength values were observed in cutlets made from cooked mince compared to the cutlets from raw mince. Cutlets from all the lots were sensorially acceptable but there was no significant difference ( $p>0.05)$ found between cutlets made from raw and cooked mince with or without potato, batter and bread crumbs. Hence, sensorially acceptable cutlets from pangas catfish mince can be prepared using any of the eight combinations studied based on the requirement or economic viability.
\end{abstract}

Keywords: Pangas catfish, cutlets, texture profile analysis, quality and sensorial acceptability.

\section{INTRODUCTION}

In 2010 the world fish production was around 145.1 Metric Tons (MT), with contribution of 45.1 MT from fresh water sources, mainly from culture practices (FAO, 2010). The fish production in India is different from the world scenario, wherein 4.61 MT have been obtained from inland sources (mainly aquaculture) and 2.99 MT from marine sources during the year 2008-09 (Pandian, 2010). Processing of fish and new fish products development can provide better sale of fish, not only in traditional fish markets, but also in all other consumer goods stores. Pangas catfish (Pangasius pangasius) is gaining popularity in Punjab due to its availability, low

* Corresponding author email: vijayreddy.surasani@gmail.com

Received: 12.01.2016 
price and absence of intramuscular spines and bones. There is a scope for increasing pangas marketing further in Punjab by developing value added convenient fish products to meet the market demand. Developing these products from pangas can increase consumer acceptability and profitability in coming period. Ready to eat mince based fish products are gaining popularity due to convenience, ease in consumption and availability in concentrated forms.

Composition and textural attributes play a vital role in popularizing a food product. Chemical composition is an important indicator of food nutritional quality. On the other hand, texture and flavour appear to be the most important attributes for the consumer (Stow, 1995). Texture of a product can be analyzed by using tests like Texture Profile Analysis (TPA), penetration test and cutting test, etc.

The important attributes of foods like taste, flavour, odour, etc. can be known only by the sensory analysis, which is the most reliable method in food analysis. Moreover, food texture is a collective term that covers several related physical properties, and this means that instrumental analysis cannot fully simulate the overall experience of texture. Instead, instrumental analysis measures specific textural properties (MØrkØre and Einen, 2003). So there is a need for sensory analysis along with the instrumental analysis, as both are important in designing a new food product.

With this rationale the objectives of the study were set to prepare cutlets using minced meat from pangas catfish in different combinations; to study their nutritional composition, textural quality as well as acceptability.

\section{MATERIALS AND METHODS}

The pangas fish with an average weight and length of $550 \pm 20 \mathrm{~g}$ and $30 \pm 5$ $\mathrm{cm}$ respectively, were procured from the farm at Fisheries College, GADVASU, Ludhiana on 12 November 2015. The collected fish was brought to the fish processing laboratory under iced condition. The fish was washed with chilled water, followed by beheading, gutting, de-skinning and thorough washing with chilled water. The dressed fish was divided into two lots, of which one lot was cooked (boiled) at $100^{\circ} \mathrm{C}$ for 30 minutes and the other was used without cooking. Simultaneously, potato was peeled and cooked at $100^{\circ} \mathrm{C}$ in boiling water for 30 minutes (Reddy and Sachin, 2015). Both the cooked and raw fish meat were deboned using a fish meat deboner (Central Institute of Fishery Technology, Cochin, India), and minced using a meat mincer (Kenwood, India).

The minced meat from both cooked and raw fish was used to prepare uniform size cutlets $(5 \times 3 \mathrm{~cm})$ with an average weight of $35 \pm 3$ grams, in eight different combinations such as cutlets made using raw mince (RM), raw mince that were battered and breaded (RMBB), raw mince with cooked potato (RMP), raw mince with cooked potato that were battered and breaded (RMPBB), cooked mince (CM), cooked mince that were battered and breaded (CMBB), cooked mince with cooked 
potato (CMP), cooked mince with cooked potato that were battered and breaded (CMPBB). The prepared cutlets were deep-fried in refined vegetable oil using a deep fat fryer at $180^{\circ} \mathrm{C}$ for $150 \mathrm{sec}$. These fried cutlets were cooled down in a desiccator and used for analyzing nutritional value, textural quality and sensory acceptability. The flow diagram for the preparation of the different pangas meat cutlet is as shown in figure 1 , and the list of ingredients is given in table 1.

\section{Proximate analysis of fish meat and cutlets}

The moisture, ash and fat content of the fish as well as cutlets were determined by the method of AOAC, 2000 (AOAC 950.46, 920.153 and 948.15). The crude protein content was determined by estimating the total nitrogen content by the method of AOAC, 2000 (AOAC 981.10). The protein content of sample was obtained by multiplying the nitrogen value by a factor of 6.25 . 
Vijay Kumar Reddy. S.

\section{Instrumental texture analysis}

Texture profile analysis (TPA)

Texture profile analysis was performed as per the method used by Reddy and Khairnar (2015). The size of the cutlet used for TPA (two-cycle compression test) was $3.0 \mathrm{~cm} \times 4.0 \mathrm{~cm}$ (diameter $\times$ height). TPA was carried out using a Taxt-plus Texture Analyzer (Stable Micro Systems Ltd., Surrey, UK), attached with a $50 \mathrm{~kg}$ load cell. A $75 \mathrm{~mm}$ diameter compression platen was used with a pre test speed of 1 $\mathrm{mm} \mathrm{sec}{ }^{-1}$; test speed of $1 \mathrm{~mm} \mathrm{sec}^{-1}$ and post-test speed of $5 \mathrm{~mm} \mathrm{sec}^{-1}$. The cutlets were compressed twice to $40 \%$ of the original height at room temperature $\left(30^{\circ} \mathrm{C}\right)$ in auto force mode $(20 \mathrm{~g})$ and the time gap between first and second compression was $5 \mathrm{sec}$. Six measurements were made for each sample in the same lot and the average value was reported for each parameter. A force-time graph was generated with data acquisition rate of $200 \mathrm{pps}$ and textural parameters like hardness, cohesiveness, adhesiveness, springiness, brittleness or fracturability, resilience, gumminess and chewiness were calculated with the aid of a software provided along with the instrument.

\section{Cutting test}

The size of the cutlet used for cutting test was $3.0 \mathrm{~cm} \mathrm{x} 4.0 \mathrm{~cm}$ (diameter $\mathrm{x}$ height). Cutting test was carried out using a Taxt-plus Texture Analyzer (Stable Micro Systems Ltd., Surrey, UK), attached with a $50 \mathrm{~kg}$ load cell. A blade set (HDP/BSW) was used with a pre test speed of $2 \mathrm{~mm} \mathrm{sec}^{-1}$; test speed of $2 \mathrm{~mm} \mathrm{sec}^{-1}$ and post-test speed of $10 \mathrm{~mm} \mathrm{sec}^{-1}$. The cutlets were compressed to $20 \mathrm{~mm}$ at room temperature $\left(30^{\circ} \mathrm{C}\right)$ in auto force mode $(20 \mathrm{~g})$. Six measurements were made for each sample in the same lot and the average value was reported for each parameter. A force-time graph was generated with data acquisition rate of $200 \mathrm{pps}$ and textural parameters like cutting strength, distance at failure and work of shear were calculated with the help of software provided along with the instrument.

\section{Penetration test}

The size of the cutlet used for penetration test was $3.0 \mathrm{~cm}$ x $4.0 \mathrm{~cm}$ (diameter $\mathrm{x}$ height). Penetration test was carried out using a Taxt-plus Texture Analyzer (Stable Micro Systems Ltd., Surrey, UK), attached with a $50 \mathrm{~kg}$ load cell. A $2 \mathrm{~mm}$ penetration probe was used with a pre test speed of $1 \mathrm{~mm} \mathrm{sec}{ }^{-1}$; test speed of $1 \mathrm{~mm}$ $\mathrm{sec}^{-1}$ and post-test speed of $5 \mathrm{~mm} \mathrm{sec}^{-1}$. The cutlets were penetrated to $15 \mathrm{~mm}$ at room temperature $\left(30^{\circ} \mathrm{C}\right)$ in auto force mode $(10 \mathrm{~g})$. Six measurements were made for each sample in the same lot and the average value was reported for each parameter. A force-time graph was generated with data acquisition rate of 200 pps and textural parameters like cutting strength, distance at failure and work of shear were calculated with the help of software provided along with the instrument. 
Table 1. Composition of ingredients mixture used in cutlet preparation

\begin{tabular}{|c|c|c|c|c|c|}
\hline \multirow[t]{2}{*}{ No } & \multicolumn{2}{|l|}{ Ingredients } & \multicolumn{3}{|c|}{ Quantity used ( g ) } \\
\hline & & $\begin{array}{c}\mathrm{RM} \& \mathrm{CM} \\
\text { cutlets }\end{array}$ & $\begin{array}{c}\text { RMP \& } \\
\text { CMP } \\
\text { cutlets }\end{array}$ & $\begin{array}{c}\text { RMBB \& } \\
\text { CMBB } \\
\text { cutlets }\end{array}$ & $\begin{array}{c}\text { RMPBB \& } \\
\text { CMPBB } \\
\text { cutlets }\end{array}$ \\
\hline 1. & Minced meat & 100.0 & 50.0 & 100.0 & 50.0 \\
\hline 2. & Potato & 0.00 & 50.00 & 0.00 & 50.00 \\
\hline 3. & Onion & 7.50 & 7.50 & 7.50 & 7.50 \\
\hline 4. & Garlic & 2.00 & 2.00 & 2.00 & 2.00 \\
\hline 5. & Green chillies & 2.50 & 2.50 & 2.50 & 2.50 \\
\hline 6. & Vegetable oil & 2.00 & 2.00 & 2.00 & 2.00 \\
\hline 7. & Chili powder & 0.25 & 0.25 & 0.25 & 0.25 \\
\hline 8. & Salt & 0.25 & 0.25 & 0.25 & 0.25 \\
\hline 9. & Ginger & 2.00 & 2.00 & 2.00 & 2.00 \\
\hline 10. & Pepper & 0.25 & 0.25 & 0.25 & 0.25 \\
\hline 11. & Turmeric powder & 0.25 & 0.25 & 0.25 & 0.25 \\
\hline 12. & Garam masala & 0.25 & 0.25 & 0.25 & 0.25 \\
\hline 13. & Batter & 0.00 & 0.00 & 1.00 & 1.00 \\
\hline 14. & Bread crumb & 0.00 & 0.00 & 0.50 & 0.50 \\
\hline
\end{tabular}

\section{Sensory analysis}

The cutlets prepared from pangas mince were served at room temperature to each judge for sensory analysis. Sensory analyses were done based on a 9-point hedonic scale (from 9 - extremely like, 5 - neither like nor dislike, to 1 - extremely dislike) by ten experienced panelists as per the method given by Peryam and Pilgrim (1957).

\section{Statistical analysis}

Statistical analysis of data was performed with the statistical package (SPSS 20.0 for windows, SPSS Inc., Richmond, CA, USA). The assumption of homogeneity of variances was tested for all data, which were log transformed if necessary. The data obtained was analyzed through analysis of variance followed by Tukey test for Posthoc analysis. 


\section{RESULTS \& DISCUSSION}

\section{Nutritional Composition}

Composition of raw material plays a significant role in affecting the composition and textural properties of the finished products. The proximate composition of pangas meat and cutlets made in eight different combinations from its mince is given in table 2 . No significant difference $(\mathrm{p}>0.05)$ was observed in nutritional composition of cutlets made in different combinations.

Table 2. Proximate composition of pangas catfish meat and cutlets

\begin{tabular}{c|c|c|c|c}
\hline Component & Moisture & Protein & Lipids & Ash \\
\hline Fish meat & $70.64 \pm 0.25$ & $\begin{array}{c}16.58 \pm 0.19^{\text {bcd }} \\
\text { Cutlets }\end{array}$ & $11.26 \pm 0.24^{\mathrm{a}}$ & $1.18 \pm 0.01^{\mathrm{a}}$ \\
RM & $68.88 \pm 0.16$ & $15.68 \pm 0.07^{\mathrm{b}}$ & $12.97 \pm 0.09^{\mathrm{bcd}}$ & $1.81 \pm 0.03^{\mathrm{ab}}$ \\
RMP & $65.93 \pm 0.09$ & $13.37 \pm 0.38^{\mathrm{a}}$ & $11.11 \pm 0.06^{\mathrm{a}}$ & $5.20 \pm 0.02^{\mathrm{d}}$ \\
RMBB & $68.41 \pm 0.15$ & $15.91 \pm 0.04^{\mathrm{bc}}$ & $12.46 \pm 0.15^{\mathrm{bc}}$ & $2.34 \pm 0.05^{\mathrm{bc}}$ \\
RMPBB & $65.74 \pm 0.13$ & $13.73 \pm 0.08^{\mathrm{a}}$ & $11.05 \pm 0.14^{\mathrm{a}}$ & $5.34 \pm 0.11^{\mathrm{d}}$ \\
CM & $63.96 \pm 0.05$ & $19.53 \pm 0.17^{\mathrm{e}}$ & $13.98 \pm 0.07^{\mathrm{d}}$ & $2.14 \pm 0.02^{\mathrm{bc}}$ \\
CMP & $61.61 \pm 0.15$ & $17.04 \pm 0.16^{\mathrm{cd}}$ & $12.17 \pm 0.21^{\mathrm{ab}}$ & $5.31 \pm 0.01^{\mathrm{d}}$ \\
CMBB & $63.58 \pm 0.16$ & $19.73 \pm 0.01^{\mathrm{e}}$ & $13.38 \pm 0.16^{\mathrm{cd}}$ & $2.72 \pm 0.08^{\mathrm{c}}$ \\
CMPBB & $61.22 \pm 0.15$ & $17.53 \pm 0.14^{\mathrm{d}}$ & $12.05 \pm 0.13^{\mathrm{ab}}$ & $5.59 \pm 0.22^{\mathrm{d}}$ \\
\hline
\end{tabular}

Means along a column bearing different superscripts differ significantly $(\mathrm{P}<0.05)$, where as means without superscripts do not differ significantly. RM: Raw mince; RMP: Raw mince with potato; RMBB: Raw mince battered and breaded; RMPBB: Raw mince with potato battered and breaded; CM: Cooked mince; CMP: Cooked mince with potato; CMBB: Cooked mince battered and breaded; CMPBB: Cooked mince with potato battered and breaded.

The high fat content in the cutlets was attributed to the fat content of pangas meat and absorption of oil during frying. Chetena et. al. (2014) reported that cutlets with $50 \%$ added potato showed reduced moisture and protein content, which was not in agreement with present study. There was no significant difference found in protein content between cutlets that were battered and not battered, despite of presence of egg protein in the batter mixture.

\section{Texture Profile Analysis (TPA) of cutlets}

Texture profile is affected by many processing factors such as the type and amount of ingredients, additives, heat treatment and equipment used (Yetim, 2000). The texture profile analysis of the cutlets prepared from pangas mince is given in table 3 . 
Hardness is related to the strength of gel structure under compression and is the peak force during first compression cycle (Chandra and Shamasundar, 2014). Cutlets from raw mince and cooked mince showed significant difference $(p<0.05)$ in their hardness and the cutlets from raw mince consistently showed higher hardness than the batch from cooked pangas mince. High hardness values for cutlets made from raw mince were due to high gel strength that needed more energy to break the structure. Low hardness values in cutlets made from cooked meat were due to destruction of gel structure during the initial cooking treatment. Low cohesiveness values of cutlets from cooked meat indicate low bonding strength.

Table 3. Texture Profile analysis of cutlets prepared from raw and cooked minced meat of pangas catfish

\begin{tabular}{|c|c|c|c|c|c|c|c|c|}
\hline Attributes & $\mathrm{RM}$ & RMP & RMBB & RMPBB & $\mathrm{CM}$ & CMP & CMBB & CMPBB \\
\hline Hardness $(g)$ & $\begin{array}{c}7228.48 \pm \\
177.23^{\mathrm{c}}\end{array}$ & $\begin{array}{c}7264.32 \pm \\
55.52^{\mathrm{c}}\end{array}$ & $\begin{array}{c}7775.21 \pm 1 \\
37.38^{\mathrm{c}}\end{array}$ & $\begin{array}{c}8067.78 \pm 22 \\
3.49^{c}\end{array}$ & $\begin{array}{c}3507.38 \pm 7 \\
5.83^{\mathrm{a}}\end{array}$ & $\begin{array}{c}2501.78 \pm 10 \\
2.27^{\mathrm{a}}\end{array}$ & $\begin{array}{c}5652.60 \pm 1 \\
44.68^{\mathrm{b}}\end{array}$ & $\begin{array}{c}3329.10 \pm 88 . \\
78^{\mathrm{a}}\end{array}$ \\
\hline $\begin{array}{l}\text { Fracturability } \\
\quad(\mathrm{g})\end{array}$ & - & - & - & - & - & - & - & - \\
\hline Adhesiveness & $\begin{array}{c}-0.70 \pm \\
0.18\end{array}$ & $\begin{array}{c}-2.01 \pm \\
0.31\end{array}$ & $\begin{array}{c}-0.36 \pm \\
0.05\end{array}$ & $-1.77 \pm 0.29$ & $\begin{array}{l}-1.83 \pm \\
0.15\end{array}$ & $-0.95 \pm 0.16$ & $\begin{array}{c}-1.24 \pm \\
0.25\end{array}$ & $-1.10 \pm 0.10$ \\
\hline Springines & $\begin{array}{l}0.748 \pm \\
0.01^{\mathrm{c}}\end{array}$ & $\begin{array}{l}0.748 \pm \\
0.01^{c}\end{array}$ & $\begin{array}{l}0.763 \pm \\
0.01^{\mathrm{c}}\end{array}$ & $\begin{array}{l}0.739 \pm \\
0.01^{\mathrm{c}}\end{array}$ & $\begin{array}{l}0.625 \pm \\
0.01^{\mathrm{b}}\end{array}$ & $\begin{array}{l}0.387 \pm \\
0.01^{\mathrm{a}}\end{array}$ & $\begin{array}{l}0.628 \pm \\
0.01^{\mathrm{b}}\end{array}$ & $\begin{array}{c}0.402 \pm \\
0.007^{\mathrm{a}}\end{array}$ \\
\hline Cohesiveness & $\begin{array}{l}0.55 \pm \\
0.01^{\mathrm{d}}\end{array}$ & $\begin{array}{c}0.42 \pm \\
0.01^{\mathrm{b}}\end{array}$ & $\begin{array}{l}0.55 \pm \\
0.01^{\mathrm{d}}\end{array}$ & $0.46 \pm 0.01^{\mathrm{c}}$ & $\begin{array}{l}0.42 \pm \\
0.01^{\mathrm{b}}\end{array}$ & $0.28 \pm 0.01^{\mathrm{a}}$ & $\begin{array}{l}0.47 \pm \\
0.01^{c}\end{array}$ & $0.30 \pm 0.01^{\mathrm{a}}$ \\
\hline Gumminess & $\begin{array}{r}4019.48 \pm \\
108.05^{\mathrm{d}}\end{array}$ & $\begin{array}{c}3067.73 \pm \\
32.14^{\mathrm{c}}\end{array}$ & $\begin{array}{c}4323.81 \pm 1 \\
14.03^{\mathrm{d}}\end{array}$ & $\begin{array}{c}3778.38 \pm 12 \\
6.61^{\mathrm{d}}\end{array}$ & $\begin{array}{c}1491.69 \pm 2 \\
6.78^{\mathrm{b}}\end{array}$ & $\begin{array}{l}720.12 \\
\pm 24.62^{\mathrm{a}}\end{array}$ & $\begin{array}{c}2678.05 \pm 8 \\
9.80^{c}\end{array}$ & $\begin{array}{c}1027.62 \pm 36 \\
32^{\mathrm{ab}}\end{array}$ \\
\hline Chewiness & $\begin{array}{c}3011.26 \pm \\
106.11^{\mathrm{d}}\end{array}$ & $\begin{array}{c}2296.58 \pm \\
38.17^{\mathrm{bc}}\end{array}$ & $\begin{array}{c}3318.98 \pm 1 \\
24.54^{\mathrm{d}}\end{array}$ & $\begin{array}{c}2805.94 \pm 11 \\
5.95^{\text {cd }}\end{array}$ & $\begin{array}{c}933.85 \pm 24 \\
64^{\mathrm{a}}\end{array}$ & $\begin{array}{l}281.56 \\
\pm 16.95^{\mathrm{a}}\end{array}$ & $\begin{array}{c}1684.01 \pm 6 \\
2.94^{\mathrm{b}}\end{array}$ & $\begin{array}{c}415.74 \pm \\
18.80^{\mathrm{a}}\end{array}$ \\
\hline Resilience & $\begin{array}{c}0.21 \pm \\
0.01^{\mathrm{e}}\end{array}$ & $\begin{array}{l}0.13 \pm \\
0.01^{\mathrm{bc}}\end{array}$ & $\begin{array}{c}0.21 \pm \\
0.01^{\mathrm{e}}\end{array}$ & $0.16 \pm 0.01^{\mathrm{d}}$ & $\begin{array}{l}0.12 \pm \\
0.01^{\mathrm{b}}\end{array}$ & $0.07 \pm 0.01^{\mathrm{a}}$ & $\begin{array}{l}0.14 \pm \\
0.01^{\text {cd }}\end{array}$ & $0.09 \pm 0.01^{\mathrm{a}}$ \\
\hline
\end{tabular}

Means across the rows bearing different superscripts differ significantly $(\mathrm{P}<0.05)$. RM: Raw mince; RMP: Raw mince with potato; RMBB: Raw mince battered and breaded; RMPBB: Raw mince with potato battered and breaded; CM: Cooked mince; CMP: Cooked mince with potato; CMBB: Cooked mince battered and breaded; CMPBB: Cooked mince with potato battered and breaded.

Fracturability is defined as the force at the first significant break in the TPA curve. In this study no fracturability was observed in any of the cutlets. The cutlets from different lots were not differed significantly $(p>0.05)$ in their adhesiveness. There was no significant difference found between the springiness of cutlets made from raw pangas meat, and these cutlets consistently showed higher springiness than the batch from cooked pangas meat. Cutlets from different lots differed significantly $(\mathrm{p}<0.05)$ in cohesiveness values with maximum values in cutlets from RM and RMBB lots. The values for gumminess in cutlets from different lots differed significantly $(\mathrm{p}<0.05)$ and except for RMP, the maximum values for gumminess were found for cutlets made from raw mince (RM, RMBB, RMPBB). The values for 
chewiness in cutlets from different lots differed significantly $(\mathrm{p}<0.05)$ and the maximum values were found for cutlets from RMBB and RM lots. Resilience in cutlets from different lots differed significantly $(\mathrm{p}<0.05)$ and the maximum values were found for cutlets from RMBB and RM lots. The differences in textural properties of cutlets made in different combinations were due to the difference in composition

\section{Cutting test of the cutlets}

Cutting test was conducted to know the toughness of the cutlets and the strength required to cut it. The results for cutting test are given in table 4 . Cutting strength values showed significant difference $(\mathrm{p}<0.05)$ between the cutlets made in different combinations. Higher cutting strength was observed in cutlets made from raw mince, with maximum cutting strength shown in cutlets from RMBB and RM lots. The differences in cutting strength values of cutlets are due to the differences in processing and composition. The less strength in cutlets made from cooked mince might be due to the softening of muscle on cooking. Cutting strength values followed a similar pattern to that of hardness values in the penetration test.

Table 4. Cutting test of cutlets prepared from raw and cooked minced meat of pangas catfish

\begin{tabular}{|c|c|c|c|c|c|c|c|c|}
\hline Attributes & $\mathrm{RM}$ & RMP & RMBB & RMPBB & $\mathrm{CM}$ & CMP & CMBB & СМРBB \\
\hline $\begin{array}{l}\text { Cutting } \\
\text { strength } \\
\text { (N) }\end{array}$ & $18.09 \pm 0.27^{\text {cd }}$ & $16.20 \pm 0.47$ & $21.97 \pm 0.69^{\mathrm{d}}$ & $15.90 \pm 0.35$ & $8.72 \pm 0.50^{b}$ & $3.65 \pm 0.06^{\mathrm{a}}$ & $10.48 \pm$ & $6.35 \pm$ \\
\hline $\begin{array}{l}\text { Distance at } \\
\text { Failure } \\
(\mathrm{mm})\end{array}$ & $36.63 \pm 0.37^{\mathrm{b}}$ & $39.95 \pm 0.29$ & $38.98 \pm 0.35^{\mathrm{bc}}$ & $39.86 \pm 0.21$ & $\underset{\mathrm{a}}{32.82 \pm 0.16}$ & $\underset{\mathrm{de}}{42.83 \pm 0.31}$ & $41.29 \pm 0.42^{\mathrm{c}}$ & $44.00 \pm 0.13^{\mathrm{e}}$ \\
\hline $\begin{array}{c}\text { Work of } \\
\text { shear (N. } \\
\text { Sec) }\end{array}$ & $107.48 \pm \underset{e}{ \pm 1.5} 6^{\mathrm{d}}$ & $\begin{array}{c}93.65 \\
\pm 2.15^{\mathrm{d}}\end{array}$ & $\underset{\mathrm{e}}{120.39 \pm 3.58}$ & $\begin{array}{c}96.04 \pm \\
1.20^{\mathrm{d}}\end{array}$ & $\underset{\mathrm{bc}}{48.14 \pm 1.33}$ & $\underset{\mathrm{a}}{24.88 \pm 0.65}$ & $\begin{array}{c}65.56 \pm \\
1.36^{\mathrm{c}}\end{array}$ & $40.55 \underset{b}{ \pm 0.75^{a}}$ \\
\hline
\end{tabular}

Means across the rows bearing different superscripts differ significantly $(\mathrm{P}<0.05)$. RM: Raw mince; RMP: Raw mince with potato; RMBB: Raw mince battered and breaded; RMPBB: Raw mince with potato battered and breaded; CM: Cooked mince; CMP: Cooked mince with potato; CMBB: Cooked mince battered and breaded; CMPBB: Cooked mince with potato battered and breaded.

\section{Penetration test of the cutlets}

Penetration test (Table 5) was conducted to know the hardness, stickiness and stringiness of the cutlets. No significant difference was found in any of these values between cutlets from different lots. 
Table 5. Penetration test of cutlets prepared from raw and cooked minced meat of pangas catfishs

\begin{tabular}{ccccccccc}
\hline Attributes & RM & RMP & RMBB & RMPBB & CM & CMP & CMBB & CMPBB \\
\hline Hardness & $178.20 \pm$ & $121.79 \pm$ & $187.35 \pm$ & $154.28 \pm$ & $98.09 \pm$ & $43.63 \pm$ & $122.33 \pm$ & $111.03 \pm$ \\
$(\mathrm{g})$ & $5.09^{\mathrm{bc}}$ & $10.65^{\mathrm{abc}}$ & $3.66^{\mathrm{c}}$ & $13.16^{\mathrm{bc}}$ & $7.15^{\mathrm{ab}}$ & $1.48^{\mathrm{a}}$ & $7.82^{\mathrm{abc}}$ & $11.79^{\mathrm{abc}}$ \\
Stickiness & $-27.17 \pm$ & $-23.81 \pm$ & $-29.60 \pm$ & $-28.38 \pm$ & $-17.87 \pm$ & $-16.30 \pm$ & $-29.40 \pm$ & $-20.37 \pm$ \\
$(\mathrm{g})$ & $0.39^{\mathrm{ab}}$ & $0.46^{\mathrm{ab}}$ & $0.30^{\mathrm{a}}$ & $1.33^{\mathrm{a}}$ & $1.47^{\mathrm{ab}}$ & $0.86^{\mathrm{b}}$ & $0.69^{\mathrm{a}}$ & $2.43^{\mathrm{ab}}$ \\
Stringiness & $0.46 \pm$ & $0.48 \pm$ & $0.91 \pm$ & $0.883 \pm$ & $23.40 \pm$ & $27.01 \pm$ & $7.86 \pm$ & $12.50 \pm$ \\
$(\mathrm{mm})$ & $0.01^{\mathrm{a}}$ & $0.02^{\mathrm{a}}$ & $0.09^{\mathrm{a}}$ & $0.12^{\mathrm{a}}$ & $0.75^{\mathrm{bc}}$ & $0.41^{\mathrm{c}}$ & $3.27^{\mathrm{a}}$ & $2.69^{\mathrm{ab}}$ \\
\hline
\end{tabular}

Means across the row bearing different superscripts are significantly different $(\mathrm{P}<0.05)$. RM: Raw mince; RMP: Raw mince with potato; RMBB: Raw mince battered and breaded; RMPBB: Raw mince with potato battered and breaded; CM: Cooked mince; CMP: Cooked mince with potato; CMBB: Cooked mince battered and breaded; CMPBB: Cooked mince with potato battered and breaded.

Table 6. Sensory attributes of cutlets prepared from raw and cooked minced meat of pangas catfish

\begin{tabular}{ccccccccccc}
\hline \multirow{2}{*}{ Attributes } & RM & RMP & RMBB & RMPBB & CM & CMP & CMBB & CMPBB \\
& & & & & & & & \\
Color & $7.25 \pm$ & $7.43 \pm$ & $7.63 \pm$ & $7.63 \pm$ & $8.00 \pm$ & $7.88 \pm$ & $7.63 \pm$ & $7.88 \pm$ \\
& 0.09 & 0.12 & 0.09 & 0.11 & 0.12 & 0.10 & 0.09 & 0.04 \\
Texture & $7.25 \pm$ & $6.71 \pm$ & $7.13 \pm$ & $7.50 \pm$ & $7.50 \pm$ & $8.00 \pm$ & $7.38 \pm$ & $7.88 \pm$ \\
& 0.11 & 0.16 & 0.10 & 0.09 & 0.13 & 0.13 & 0.09 & 0.08 \\
Flavor & $7.62 \pm$ & $7.14 \pm$ & $7.38 \pm$ & $7.25 \pm$ & $7.50 \pm$ & $7.88 \pm$ & $7.75 \pm$ & $7.88 \pm$ \\
& 0.06 & 0.15 & 0.06 & 0.11 & 0.13 & 0.10 & 0.11 & 0.08 \\
Chewiness & $7.50 \pm$ & $7.71 \pm$ & $6.38 \pm$ & $7.25 \pm$ & $7.50 \pm$ & $7.50 \pm$ & $7.25 \pm$ & $7.50 \pm$ \\
& 0.12 & 0.11 & 0.09 & 0.09 & 0.12 & 0.13 & 0.11 & 0.07 \\
Odor & $7.38 \pm$ & $7.43 \pm$ & $7.13 \pm$ & $7.75 \pm$ & $7.50 \pm$ & $7.88 \pm$ & $7.38 \pm$ & $7.50 \pm$ \\
& 0.06 & 0.16 & 0.08 & 0.09 & 0.09 & 0.08 & 0.16 & 0.09 \\
Appearance & $7.13 \pm$ & $7.57 \pm$ & $7.75 \pm$ & $7.88 \pm$ & $7.50 \pm$ & $7.63 \pm$ & $8.13 \pm$ & $7.88 \pm$ \\
& 0.10 & 0.12 & 0.06 & 0.08 & 0.09 & 0.11 & 0.04 & 0.08 \\
Adhesiveness & $7.13 \pm$ & $7.29 \pm$ & $6.88 \pm$ & $7.50 \pm$ & $7.50 \pm$ & $7.38 \pm$ & $7.63 \pm$ & $7.25 \pm$ \\
& 0.08 & 0.12 & 0.16 & 0.12 & 0.12 & 0.15 & 0.09 & 0.09 \\
Meatiness & $7.63 \pm$ & $7.14 \pm$ & $7.25 \pm$ & $7.50 \pm$ & $7.88 \pm$ & $7.75 \pm$ & $7.75 \pm$ & $7.75 \pm$ \\
& 0.11 & 0.15 & 0.09 & 0.12 & 0.10 & 0.15 & 0.09 & 0.06 \\
Spiciness & $7.13 \pm$ & $7.57 \pm$ & $7.38 \pm$ & $7.75 \pm$ & $7.38 \pm$ & $7.75 \pm$ & $7.63 \pm$ & $7.63 \pm$ \\
& 0.08 & 0.12 & 0.09 & 0.09 & 0.11 & 0.11 & 0.09 & 0.09 \\
Hardness & $7.38 \pm$ & $7.57 \pm$ & $7.00 \pm$ & $6.75 \pm$ & $7.38 \pm$ & $7.38 \pm$ & $7.38 \pm$ & $7.88 \pm$ \\
& 0.06 & 0.10 & 0.13 & 0.11 & 0.15 & 0.16 & 0.09 & 0.08 \\
Saltiness & $7.63 \pm$ & $7.71 \pm$ & $7.63 \pm$ & $7.63 \pm$ & $6.75 \pm$ & $7.88 \pm$ & $7.13 \pm$ & $7.88 \pm$ \\
Overall & 0.06 & 0.09 & 0.06 & 0.11 & 0.13 & 0.12 & 0.16 & 0.08 \\
acceptability & $7.50 \pm$ & $7.14 \pm$ & $7.38 \pm$ & $7.38 \pm$ & $7.25 \pm$ & $7.88 \pm$ & $7.75 \pm$ & $8.00 \pm$ \\
\hline \multirow{2}{*}{ No } & 0.09 & 0.15 & 0.06 & 0.09 & 0.13 & 0.14 & 0.09 & 0.07 \\
\hline
\end{tabular}

No significant difference in any attribute. RM: Raw mince; RMP: Raw mince with potato; RMBB: Raw mince battered and breaded; RMPBB: Raw mince with potato battered and breaded; CM: Cooked mince; CMP: Cooked mince with potato; CMBB: Cooked mince battered and breaded; CMPBB: Cooked mince with potato battered and breaded. 
Vijay Kumar Reddy. S.

\section{Sensory analysis of cutlets}

Scores for the sensory attributes of cutlets made in eight different combinations are given in table 6. No significant difference was found between cutlets from different lots in any of the sensory attributes. All the cutlets made in different combinations were sensorially acceptable with over all acceptable scores of more than 7.0.

Textural determination equipments (including Textural Profiles Analyzer) can be used to determine differences in texture among different treatment samples, whereas textural determination based on the sensorial test is preferred by consumers (Nurul et al., 2010). The sensory scores above five indicated that pangas cutlets prepared in eight different combinations were sensorially acceptable. During their studies on cutlets Ahamaed et al. (2006), Pawar et al. (2012), Chetena, et. al. (2014) and Singh et al. (2014) reported that, addition of potato and application of enrobing could improve the acceptability of cutlets, which was not observed in the present study.

\section{CONCLUSION}

Based on the results, this study shows that different processing methods like cooking of meat, addition of potato, application of battering and breading do not significantly affect the nutritional composition, textural quality and sensorial acceptability of pangas cutlets. By using any of these combinations, cutlets can be prepared from pangas minced meat with good quality and sensorial acceptability. The method to be used for preparing cutlets can be selected based on the availability of materials, final product quality and economic viability. More study is needed in this area to study the exact effect of individual ingredients and process on properties of finished product.

\section{ACKNOWLEDGEMENT}

Authors are very much thankful to Mr. Vishal Sharma, $3^{\text {rd }}$ year BFSc student, GADVASU and Dr. Bhaskar Vemu, Ph.D. student, Dept. Vet. Pharmacology, GADVASU, for their technical help during the work.

\section{REFERENCES}

Ahamed, M. E., Anjaneyulu, A. S. R., Sathu, T., Thomas, R. and Kondaiah, N. 2006. Effect of enrobing on the quality and shelf life of buffalo meat cutlets under frozen storage. Journal of Muscle Foods, 18 (1): 19-34

AOAC. 2000. Official Methods of Analysis of AOAC International. Vol. II $16^{\text {th }}$ Edition. Association of Official and Analytical Chemists International, Virginia, USA

Bhale, S. D. 2004. Effect of ohmic heating on color, rehydration and textural characteristics of fresh carrot cubes. Master degree dissertation, submitted to Louisiana State University and Agricultural and Mechanical College 
Brenda, C., Fermin, T. S., Hahm Julia, A., Randinsky Robert, J., Kratochvil John, E., Hall and Martino Lo, Y. 2005. Effect of proline and glutamine on the functional properties of wheat dough in winter wheat varieties. Journal of Food Science, 70: E273-E278

Burey, P., Bhandari, B. R., Rutgers, R. P. G. and Halley, P. J. 2009. Confectionery gels: A review on formulation, rheological and structural aspects. International Journal of Food Properties, 12: 176-210

Chandra, M. V. and Shamasundar, B. A. 2014. Texture Profile Analysis and Functional Properties of Gelatin from the Skin of Three Species of Fresh Water Fish. International Journal of Food Properties, 18 (3): 572-584

Chetana, P., Yogesh, K., Anita, Bharti, S. K. and Tanwar, V. K. 2014. Effect of Incorporation of Potato on the Quality of Chicken Cutlets. IOSR Journal of Agriculture and Veterinary Science, 7 (1): 12-15

FAO. 2010. The State of world fisheries and aquaculture. Food and Agricultural Organization. Rome

Kasapis, S. 2009. Developing minced fish products of improved eating quality: An inter play of instrumental and sensory texture. International Journal of Food Properties, 12: 1126

Klettner, P. G. 1993. Frankfurter-type sausage influence of heat treatment on firmness and color. Fleischwirtschaft, 73 (3): 296-298

Liu, H. Y., Han, J. and Guo, S. D. 2009. Characteristics of the gelatin extracted from Channel Catfish (Iactalurus Punctatus) head bones. Food Science and Technology, 42: 540-544

MØrkØre, T. and Einen, O. 2003. Relating sensory and instrumental texture analyses of Atlantic salmon. Journal of Food Science, 68 (4): 1492-1497

Nurul, H., Lin, O. J., Ping, Y. C. and Nurkhoeriyati, T. 2010. Effect of chicken and duck meat ratio on the properties of sausage. International Journal of Poultry Science, 9 (6): 550555

Pandian, P. P. 2010. Formulation of schemes for development of fisheries sector in XI plan (2007-2012). In: Annual Publication, Professional Fisheries Graduate Forum, Mumbai.

Pawar, P. P., Pagarkar, A. U., Rathod, N. B., Baug, T. E. and Rather, M. A. 2012. Standardisation of Recipe for Fish Cutlet Product from fresh water fish Catla (Catla Catla). European Journal of Experimental Biology, (6): 2043-2048

Peryam, D. R. and Pilgrim, F. J. 1957. Hedonic scale method of measuring food preferences. Food Technology, 11 (9): 9-14

Radocaj, O. F., Dimic, E. B. and Vujasinovic, V. B. 2011. Optimization of the texture of fatbased spread containing hull-less pumpkin (Cucurbita pepo L) seed press-cake. Acta Periodica Technologica, 42: 1-288

Rahman, M. S. and Al-Mahrouqi, A. I. 2009. Instrumental texture profile analysis of gelatin gel extracted from grouper skin and commercial (bovine and porcine) gelatin gels. International Journal of Food Science and Nutrition, 60: 229-242 
Reddy, S. V. K. and Khairnar, S. O. 2015. Textural quality and sensorial acceptability of cutlets from minced meat of three freshwater carp fish species. International Journal of Advanced Research, 3 (5): 395-403

Singh, P. K., Kumar, S., Kumar, P. and Bhat, Z. F. 2014. Effect of mincing on the quality characteristics of chevon cutlets. Journal of Animal Research, 4 (2): 193-200

Stow, J. 1995. Quality measurements of apples. Postharvest News Inform, 6: 32N-33N

Yetim, H. 2000. Kesimhane Urunleri Isleme Teknolojisi (Ders Notlari), pp. 48-79, Ataturk Universitesi Ziraat Fakultesi, Erzurum, Turkey (in Turkish) 